\title{
Can Renewable Energy Artifacts have a Global Politics? Towards a Translocal Imaginary of Energy Democracy
}

\author{
SUJATHARAMAN \\ THE AUSTRALIAN NATIONAL UNIVERSITY \\ AUSTRALIA
}

\begin{abstract}
In the 2020 Prague Virtual Conference of the Society for Social Studies of Science (4S), Langdon Winner was awarded the society's John D. Bernal Prize jointly with Sharon Traweek. The Bernal Prize is awarded annually to individuals who have made distinguished contributions to the field of STS. Prize recipients include founders of the field of STS, along with outstanding scholars who have devoted their careers to the understanding of the social dimensions of science and technology. This response to Winner's Bernal lecture considers how visions of energy democracy speak back to decarbonisation imperatives grounded in industrial-scale renewable energy technologies, and asks if these arguments might be further transnationalised.
\end{abstract}

\section{Keywords}

renewable energy; translocal; politics of artifacts; reasoning; Langdon Winner

\section{Introduction}

Some proponents of energy from renewable resources now believe they have at last discovered a set of intrinsically democratic, egalitarian, communitarian technologies. In my best estimation, however, the social consequences of building renewable energy systems will surely depend on the specific configurations of both hardware and the social institutions created to bring that energy to us (Winner 1986, 39).

As the US re-joins the Paris Agreement and President Joe Biden moves to fulfil his campaign promise of transitioning to 'clean, American-made electricity,' the future for renewable energy has never looked stronger. In the past decade, the costs of photovoltaics (PV) have fallen $82 \%$ according to figures from the International Renewable Energy Agency (IRENA 2020). If the late 1800s-early 1900s was marked in part by a race for the sky in urban buildings, the early $21^{\text {st }}$ century may come to be known, as the New York Times puts it, as the time of a 'renewable-energy arms race' (Reed 2021). Media stories marvel at GE's new wind turbine, Haliade- $\mathrm{X}$, in the breathless terms of the dimensions of landmark buildings and (presumably American) football fields. In Australia, another renewables "world's biggest" is underway, in this case, in battery technology (Morton 2021). The very fact that there now exists a trans-governmental agency dedicated to supporting the adoption of renewables (IRENA was set up in 2009) suggests we have come a long way from

Copyright (C) 2021 (Sujatha Raman). Licensed under the Creative Commons Attribution-NonCommercialNoDerivatives 4.0 International (CC BY-NC-ND 4.0). Available at estsjournal.org.

To cite this article: Raman, Sujatha. 2021. "Can Renewable Energy Artifacts have a Global Politics? Towards a Translocal Imaginary of Energy Democracy." Engaging Science, Technology, \& Society 7.1: 118-124. https://doi.org/10.17351/ests2021.961. 
the world of the old International Energy Agency (IEA) circa 1980 when the sentiments captured in the epigraph to this article appeared in print. Today, the IEA, an organization created to secure oil supplies for global North countries, collaborates closely with IRENA, its renewable energy counterpart.

Every time I come across the announcement of yet another renewable energy milestone, I cannot but be reminded of Langdon Winner's prescient observation that technologies of wind or solar power will not in themselves deliver social equality or participatory democracy. Renewables are no longer the "Cinderella options" (Grubb 1990) of the energy world. Yet, in the climate-fuelled race to build them bigger as a substitute for coal- and gas-fired power generation, renewables now seem distant from their cultural home in the appropriate technology and communitarian movements described by Winner (1986). It may be premature to declare the demise of renewable energy as a social movement as Glover (2006) did in the face of early signs that the technology was becoming "fossilized," i.e., resembling the structures of fossil fuel systems (Raman 2013). But the growth of industrial-scale renewables does present a political challenge for those seeking a democratic path away from fossil fuels.

When a centralised, large-scale renewable energy future is on offer as an essential ingredient for averting climate catastrophe, how is it possible to politicise it? Who is talking back to this vision, and on what political terms? On this occasion of the publication of Winner's Bernal lecture, I would like to briefly explore the implications of his foundational insights on technology and politics for these questions. I focus on visions of energy democracy being articulated around the world in conversation with broader concerns about democratisation as well as decarbonisation.

Let me begin with some context. My connection to Winner's work dates back to the early 2000s when I started teaching introductory STS courses at the University of Nottingham in the UK, first to political science students and later to students in sociology, (STSInfrastructures Nottingham 2018). In an alternate universe, I might have taken up a PhD place at RPI's program in STS where our paths would likely have crossed in the 1990s, but as things turned out, I went to Pittsburgh for a $\mathrm{PhD}$ in public policy before moving to the UK. The memorable ideas in The Whale and the Reactor (Winner 1986) were immensely helpful for motivating many a classroom discussion: the politics of artifacts, technologies as forms of life, technology as legislation (first introduced in Autonomous Technology). Students grappled with a new conceptual vocabulary to ask if and how, say, self-checkouts, online banking, CCTV, or biomedical technologies stacked the deck in ways that favoured some and disadvantaged others. As UK institutions created opportunities for STS academics to engage science and engineering research students in the wider social dimensions of their work, Winner's line of questioning remained fruitful for engaging with an audience otherwise unused to STS ways of thinking.

Now based in Australia in one of the world's oldest science communication centres, Australian National Centre for the Public Awareness of Science (CPAS), I find myself picking up his remarks on the importance of language for the politics of technology. "A depleted language exacerbates many problems; a lively and concrete vocabulary offers the hope of renewal," Winner observes (ibid.,163). Energy democracy faces a dual communicative challenge in this regard: one, responding effectively to the "lively and concrete" (if 
dystopian) language of planetary collapse that implicitly favours a large-scale renewable energy future, and two, doing so on a topic (energy) that is notoriously imbued in a technical language.

\section{The Politics of Reasons: or, Does Democracy Matter if the Planet is Going to be Cooked?}

In the space of just a few years, energy democracy has become the subject of an extensive literature in Energy Research and Social Science (e.g., Burke \& Stephens 2018; Lennon 2017; van Veelen \& van der Horst 2018) and associated journals (e.g., a special issue of Frontiers in Communication introduced by FeldpauschParker et al 2019, and generated a systematic review article Szulecki \& Overland 2020). This scholarship largely focuses on North America and Europe (but see Delina 2018), reflecting social movements mobilising under the term in those places. However, the International Energy Democracy Alliance aims to bring together groups from across the world; their website showcases a wider range of stories (e.g., Mauritius, Nicaragua, Palestine). Older examples of efforts to yoke together energy and democracy include Prayas Energy Group which has been building a 'Public Interest Paradigm on Energy for Development' in India since the 1990s. The work of democratising energy is also being done under other frameworks, most notably, feminist and decolonial visions of energy futures (e.g., Lennon 2017; Wilson 2018).

I use examples from across these materials to examine how renewables are made to be much more than neutral substitutions for fossil fuel-based technologies; in short, how they are politicised. I argue that renewable energy politics is coming of age with practices and visions of energy democracy, which are pushing the imaginative boundaries of responses to climate change. But there is still much work to be done to make energy democracy a trans-local, trans-national idea capable of engaging with the globally distributed politics of renewable energy systems.

Winner's (1986) keen attention to the way we reason about technology and technological change is helpful for our task. Public reasoning matters for a democratic politics of technology as it shapes who can participate, what can be said, and on what grounds. The reasons we give, challenge or accept about what is good or bad about a transcontinental missile or genetic modification are as important, Winner argues, as decisions on which laws to adopt, reject or regulate. Like another STS pioneer (Wynne 2002), he urges us to be wary of reducing such issues to matters of risk and safety. Framing the technology question in terms of decisions concerning risk, impacts, and side-effects leads us down the rabbit-hole of ever more narrowly technical considerations, inhibiting attention to the question of what kind of world we are creating (Jasanoff 2015) by bringing a new artefact into existence.

At first, large industrial-scale renewables for electricity generation appear to promise a better world by transporting us away from the horrors of global heating as well as the environmental health, socio- 
economic and geopolitical traumas inflicted by fossil fuels. ${ }^{1}$ On a closer look, this future world looks a lot like ours, with ways of organising economies, labour, systems of governance and relationships with nature fundamentally unchanged. But does this matter if scaled-up renewables will save the planet? At the time Winner was writing, resistance in the name of alternative communitarian futures may have seemed the preserve of quaint "dreamers and fools" dismissed for refusing to "accept the hard requirements and imperatives" of 'progress' (Winner 1986, 38). But today, those dreamers and fools speaking back against the imperative of a renewable arms race may be accused of avoiding an altogether harder imperative: averting planetary collapse. The politicisation of industrial renewables must be crafted and made compelling in the face of this burden.

In what follows, I explore three language families in energy democracy movements and the way they 'speak back' to the imperative of industrial renewables, while keeping the prospect of better future worlds in play.

The Rights of Community: As scholars of energy democracy observe, different coalitions define and mobilise around the term differently, but a critique of dominant market-led energy transition and a call for community ownership and control is common across these differences. In both US- (Climate Justice Alliance or CJA) and European-led (International Energy Democracy movement) versions, new models of public ownership (including worker cooperatives) feature strongly, challenging the assumption that large energy companies should remain in charge and transforming the notion of renewable energy transition as a neutral process of substituting one technology for another. Prayas Energy Group's model also has these elements, but it is more closely tied to a critique of existing policy mechanisms and recommendations for new ones in the public interest. Across this landscape, there is a strong focus on decentralized renewable energy solutions and support for livelihoods together with climate action.

The Weight of History: The focus on who owns/controls energy transition introduces an important set of reasons, grounded in the familiar language of democracy, to challenge the dominance of industrial-scale renewables. But on its own, it is not obvious how this language can address the 'hard' imperative of doing something about planetary breakdown. For this, we need to attend to those parts of energy democracy movements that draw on the weight of history to make a potentially compelling set of arguments about how justice matters both in its own right and for the future of the planet. On the landing page of their website, the Climate Justice Alliance highlights the need for climate solutions to be both 'expedient' and 'just,' and calls attention to the limits of a carbon-centric approach that ignores inequality and the history of racialized environmental injustices. Their Ten Principles for Energy Democracy then go on to show how this history matters for the ability of renewable energy transition to make good on its promise. Drawing on the notion of

${ }^{1}$ Electricity is, of course, only one part of climate transition scenarios predicted to keep global temperatures below 1.5 degC; climate experts also highlight the need for systemic change in agriculture, industry, buildings, transport and forestry, and indeed, interconnections between power generation and other sectors. 
the commons, they set out reasons for transforming our relationship to nature and ensuring that the resources given to us by this earth are not exhausted. Lennon's (2017) work on decolonizing energy takes this further, reminding us of the history of colonial and racial oppression by which energy became a 'thing' in the first place, to be produced and consumed at will - and effectively warning us that a centralized, largescale renewables transition is at risk of perpetuating such a boundless 'Big Energy' future.

The Promise of Indeterminacy: Visions of decolonial energy futures bring together and blur the boundaries between the technical language of kilowatt-hours and the apparently distinct social language of race (ibid., 2017). In this way, they challenge us to think again about the vision of planetary salvation promised by centralised industrial-scale renewables. Wilson's (2018) work does something similar by drawing attention to the 'radical indeterminacy' of the moment and hence, to new possibilities. As she puts it:

An energy transition adequate to the challenges of climate change demands of us the complete reinvention of daily-lived reality. We must rethink everything from the clothes we wear, to where those clothes are manufactured, to what we eat and where it is grown, to how we wash those clothes and dishes, to how we collect and use natural resources including water, solar, and wind - and ultimately how, and how fast (or slow), we move about in the world and how we live together in community: sharing our food, energy, shelter, labor, and lives (ibid. 2018, 393).

This may be a tall order, but debates around energy democracy suggest that some people are indeed thinking hard about what it might take - in place of a renewable energy arms race-to respond to climate change. Centralized, industrial-scale renewables are premised on the notion that we can address planetary threats without attending to the realities of everyday life in wealthy countries. Engaging in a politics of reasons, Wilson (ibid.) refuses this premise, arguing that climate change can only be addressed through social, economic, and political transformation.

Finally, the Earthworks organisation does not specifically use the language of 'energy democracy' but offers a further set of reasons for politicising renewable energy futures. Earthworks' $\underline{2019}$ letter to the World Bank brings attention to the social and environmental impacts of mining key minerals (from copper and nickel to lithium and cobalt) required for producing renewable energy technologies. These hazards are typically experienced by communities distant from the sites of renewable energy consumption, underlining the need to trans-nationalize the democratic imaginary of energy democracy. This in turn calls for cultural work to reimagine renewable energy futures (e.g., Williams (2019) on solarpunk) and further develop the language and practices of energy democracy.

Langdon Winner was keenly attentive to the difficulties of seeking to pause the innovation 'race.' It is one thing to point to the fallacies of technological fixes to climate change, including in this case, the vision of renewables as a painless solution that takes away the need to transform existing ways of life. Dismantling and redesigning the socio-technological systems that shape these 'forms of life' in industrialised countries - as Winner (1986) put it in homage to Wittgenstein-is another thing altogether. In the face of this challenge, Winner offered the evocative notion of 'epistemological luddism,' i.e., an experimental stance wherein problematic technological systems could be "temporarily at least, disconnected and made 
unworkable" (Winner 1977, 330) to create the chance to learn how things might be otherwise. In recent years, much work has been done on dampening energy demand under a different conceptual rubric to those I have considered so far in this paper. Research by the Demand Centre shows that a productive way to achieve similar ends to those put forward by Winner is to work outward from the mundane social practices of everyday life and connect them to the influence of larger-scale technological infrastructures. If renewable energy artifacts are to be politicised, we will need multiple such epistemological, political and language traditions to learn from each other in productive ways.

\section{Author Biography}

Sujatha Raman is Director of Research at the Australian National Centre for the Public Awareness of Science, Australian National University. Building on her training in STS, she is currently exploring the contribution that science communication research and practice can make to science, technology, and innovation in the public good.

\section{References}

Burke, Matthew J., and Jennie C. Stephens. 2018. "Political Power and Renewable Energy Futures: A Critical Review." Energy Research \& Social Science 35: 78-93.

Delina, Laurence L. 2018. "Energy Democracy in a Continuum: Remaking Public Engagement on Energy Transitions in Thailand." Energy Research \& Social Science 42: 53-60.

Feldpausch-Parker, Andrea M., Danielle Endres, and Tarla Rai Peterson. 2019. "Editorial: A Research Agenda for Energy Democracy." Frontiers in Communication 4: 53.

Glover, Leigh. 2006. "From Love-ins to Logos: Charting the Demise of Renewable Energy as a Social Movement." In Transforming Power: Energy, Environment, and Society in Conflict, edited by John Byrne, Noah Toly, and Leigh Glover, 249-270. NY and London: Transaction Publishers.

Grubb, Michael J. 1990. "The Cinderella Options: A Study of Modernized Renewable Energy Technologies Part 1-A Technical Assessment." In Energy Policy 18(6): 525-542.

IRENA. 2020. "Renewable Power Generation Costs in 2019." Abu Dhabi: The International Renewable Energy Agency. Accessed July 202020.

https://www.irena.org/publications/2020/Jun/Renewable-Power-Costs-in-2019.

Jasanoff, Sheila. 2015. "Future Imperfect: Science, Technology and the Imaginations of Modernity." In Dreamscapes of Modernity: Sociotechnical Imaginaries and the Fabrication of Power, edited by Sheila Jasanoff and Sang-Hyun Kim. Chicago: University of Chicago Press.

Jenkins, Kirsten E. H., Jennie C. Stephens, Tony G. Reames, and Diana Hernández. 2020. "Towards Impactful Energy Justice Research: Transforming the Power of Academic Engagement." Energy Research \& Social Science 67: 101510.

Lennon, Myles. 2017. "Decolonizing Energy: Black Lives Matter and Technoscientific Expertise Amid Solar Transitions." Energy Research \& Social Science 30: 18-27.

Morton, Adam. 2021. World's Biggest Battery with 1,200MW Capacity Set to be Built in NSW Hunter Valley. The Guardian (Australian edition), February 5.

https://www.theguardian.com/australia-news/2021/feb/05/worlds-biggest-battery-with$1200 \mathrm{mw}$-capacity-set-to-be-built-in-nsw-hunter-valley-australia. 
Raman, Sujatha. 2013. "Fossilizing Renewable Energies." Science as Culture 22(2): 172-180.

Reed, Stanley. 2021. "A Monster Wind Turbine is Upending an Industry." The New York Times, January 12021. https://www.nytimes.com/2021/01/01/business/GE-wind-turbine.html.

Szulecki, Kacper, and Indra Overland. 2020. "Energy Democracy as a Process, an Outcome and a Goal: A Conceptual Review." Energy Research \& Social Science 69: 101768.

van Veelen, Bregje, and Dan van der Horst. 2018. "What is Energy Democracy? Connecting Social Science Energy Research and Political Theory." Energy Research \& Social Science 46: 19-28.

Williams, Rhys. 2019. " 'This Shining Confluence of Magic and Technology': Solarpunk, Energy Imaginaries, and the Infrastructures of Solarity." Open Library of Humanities 5(1): 1-35

Wilson, Sheena. 2018. "Energy Imaginaries: Feminist and Decolonial Futures." In Materialism and the Critique of Energy, edited by Brent R. Bellamy and Jeff Diamanti, 377-412. Chicago and Alberta: MCM Press.

Winner, Langdon. 1977. Autonomous Technology: Techniques-out-of-Control as a Theme in Political Thought. Cambridge, MA \& London: MIT Press.

—.1986. The Whale and the Reactor. A Search for Limits in an Age of High Technology. Chicago: The University of Chicago Press.

Wynne, Brian. 2002. "Risk and Environment as Legitimatory Discourses of Technology: Reflexivity Inside Out?" Current Sociology 50(3): 459-477. 